\title{
Evaluation of Wind Potential for an Optimum Choice of Wind Turbine Generator on the Sites of Lomé, Accra, and Cotonou Located in the Gulf of Guinea
}

\author{
Akim A. Salamia, Ayité Sénah A. Ajavona* ${ }^{*}$ Mawugno K. Kodjo a and Koffi-Sa Bédjaa \\ ${ }^{a}$ Electric Renewable Energy Laboratory, Equipe de Recherche en Sciences de l'Ingénieur (ERSI), Department of Electrical Engineering, Ecole Nationale \\ Supérieure d'Ingénieurs (ENSI), University of Lomé, BP 1515, Lomé TOGO
}

\begin{abstract}
This work presents the characterization and assessment of wind energy potential in annual and monthly levels of the sites of Lomé, Accra and Cotonou located in the Gulf of Guinea, and the optimal characteristics of wind turbines to be installed on these sites. Studies of characterization and the wind potential of these sites from the wind speed data collected over a period of thirteen years at a height of 10 meters above the ground, show an annual average speed of $3.52 \mathrm{~m} / \mathrm{s}$ for Lomé, $3.99 \mathrm{~m} / \mathrm{s}$ for Cotonou and 4.16 $\mathrm{m} / \mathrm{s}$ for Accra. These studies also showed that a monthly average speed exceeding $4 \mathrm{~m} / \mathrm{s}$ was observed on the sites of Cotonou and Accra during the months of February, March, April, July, August and September and during the months of July, August and September on the site of Lomé. After a series of simulation conducted using the software named PotEol that we have developed in Scilab, we have retained that the wind turbines rated speeds of $\sim 8$ to $9 \mathrm{~m} / \mathrm{s}$ at the sites of Lomé and Cotonou and $\sim 9$ to $10 \mathrm{~m} / \mathrm{s}$ on the site of Accra would be the most appropriate speeds for optimal exploitation of electric energy from wind farms at a height of $50 \mathrm{~m}$ above the ground.
\end{abstract}

Keywords: Modeling, Wind potential, Optimal parameters choice, Wind turbine generator

Article History: Received May 26 $6^{\text {th }}$ 2016; Received in revised form August 24th 2016; Accepted August 30 ${ }^{\text {th }}$ 2016; Available online How to Cite This Article: Salami, A.A., Ajavon, A.S.A , Kodjo, M.K. and Bédja, K. (2016) Evaluation of Wind Potential for an Optimum Choice of Wind Turbine Generator on the Sites of Lomé, Accra, and Cotonou Located in the Gulf of Guinea. Int. Journal of Renewable Energy Development, 5(3), 211223.

http://dx.doi.org/10.14710/ijred.5.3.211-223

\section{Introduction}

Today, with the exhaustion of the world stock of oil, energy demand ever increasing, and the fear of increasingly alarming pollution, renewable energy sources (solar, wind etc.) are seen as ideal, clean, and inexhaustible sources of energy (Impacts et al., 2007; Sahin, 2004).

In the event that the increase in energy consumption could be offset by wind energy (clean energy), mastery of this energy is essential. The electrical energy from wind power is produced by the kinetic energy of the wind. Wind parameters vary in time and space (Sahin, 2004). Therefore, the study of the characterization of the wind distribution for different sites should be considered when installing wind energy conversion systems (Burton et al., 2001), (Ajavon et al., 2015), (Lu et al., 2002). So if conversion systems were well adapted to the site, an assessment of the wind potential and a prediction of the power produced would be made with reasonable accuracy on the site (Tong, 2010).

Several studies have shown that the Weibull distribution function is better suited to characterize the distribution of the wind on a site (Sahin, 2004; Kaldellis and Zafirakis, 2011; Manwell et al., 2002; Akdag and Dinler, 2009; Ahmed, 2013). A recent study on the site of Lomé (Togo) confirmed that the hybrid Weibull distribution function is recommended for a better fit of the distribution of wind speeds at the site where the frequency of calm winds is important (Salami et al., 2013).

In this work, the distributions of wind speeds are characterized, the optimal choice of turbines is determined, and the production of electrical energy of the three sites in the Gulf of Guinea (Lomé, Togo, Accra in Ghana and Cotonou in Benin) is evaluated. Also, changes

*Corresponding Author: (A. S. A. Ajavon) Tel: +228-90174763

Email:senajavon@hotmail.com 
Citation: Salami, A.A., Ajavon, A.S.A , Kodjo, M.K. and Bédja, K. (2016) Evaluation of Wind Potential for an Optimum Choice of Wind Turbine Generator on the Sites of Lomé, Accra, and Cotonou Located in the Gulf of Guinea. Int. Journal of Renewable Energy Development, 5(3), 211-223, doi : 10.14710/ijred.5.3.211-223

$P$ a g e $\mid 212$

in statistical parameters of the series of wind speeds and variations of recoverable and produced energy are analyzed for each month. For an accurate wind energy assessment, we have developed a software tool named PotEol to determine the characteristics of the wind, assess the wind potential, and make optimal parameters choice of a wind turbine.

\section{Data source}

Wind data series on the three sites involved in this study were obtained through meteorological databases of the University of Wyoming (Department of Atmospheric Science)('http://Wheather.uwyo.edu/surface/meteogra $\mathrm{m} /$ ', n.d.).

The data were recorded daily by one-hour interval (this is the average over the 10 minutes before the hour) at a height of $10 \mathrm{~m}$ above the ground. For this study we are particularly interested the wind speed and time of recording. The data cover the period from January 2000 to October 2012 for Lomé, Togo (where the measuring point is located at $6.17 \mathrm{~N}, 1.25 \mathrm{E}, 25$ meters) and from January 2000 to December 2012 for Accra, Ghana (where the measurement point is located at $5.60 \mathrm{~N} 0.17 \mathrm{~W}, 69$ meters) and Cotonou, Benin (where the measuring point is located at $6.35 \mathrm{~N} 2.38 \mathrm{E}, 9$ meters). The geographical location of the three (03) sites is presented in Figure 1.

The application of statistical methods on the data collected allowed us to model the distribution of wind speeds, to assess wind energy potential, and to make an optimum choice of wind turbines parameters suitable for each site.

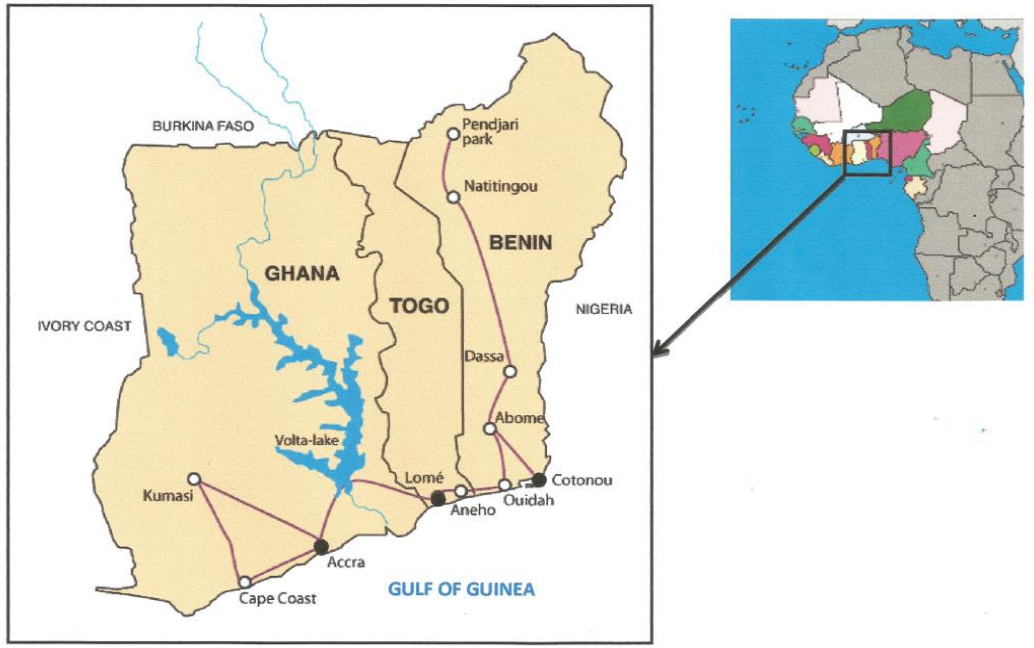

Fig. 1 Location of the study sites

\section{Methods}

In this section, we briefly introduce the hybrid Weibull function used to characterize the distribution of wind speeds, the methods used for the assessment of wind energy potential and the optimal choice of a wind turbine parameters on the three sites studied.

\subsection{Weibull Hybrid distribution}

The expression of the Hybrid Weibull function is given by Equation (1).

$$
f(V)= \begin{cases}F_{0} & \text { if } \quad V<1 \mathrm{~m} / \mathrm{s} \\ \left(1-\mathrm{F}_{0}\right)\left(\frac{\mathrm{K}}{\mathrm{C}}\right)\left(\frac{\mathrm{V}}{\mathrm{C}}\right)^{\mathrm{K}-1} \cdot \exp \left[-\left(\frac{\mathrm{V}}{\mathrm{C}}\right)^{\mathrm{K}}\right] & \text { if } \quad \mathrm{V} \geq 1 \mathrm{~m} / \mathrm{s}\end{cases}
$$

where:
- $\mathrm{F}_{0}$ represents the frequency of calm winds, which is determined from the wind data.

In this work, the values of $\mathrm{K}$ parameters (shape parameter) and $\mathrm{C}$ (scale parameter $[\mathrm{m} / \mathrm{s}]$ ) of the distribution was determined by the least squares method (Sahin, 2004; Celik, 2004; WD, 1996; Bagiorgas et al., 2011; Rocha et al., 2012).

The average speed $V_{\text {moy }}$ following the Weibull hybrid function is given by Equation (2)

$$
\mathrm{V}_{\text {moy }}=\left(1-\mathrm{F}_{0}\right) \mathrm{C} \cdot \Gamma\left(1+\frac{1}{\mathrm{~K}}\right)
$$

where:

- $\quad \Gamma$ is the gamma function.

\subsection{Wind potential}

The wind potential of a site is defined as the extractible energy during a given period of operation of 
a given wind turbine on this site, (Stankovic et al., 2009; Editorial, 2011; Jowder, 2009). It is therefore a function of the distribution of wind speeds and the windfarm characteristics installed on the site.

The assessment of wind energy potential must take into account the operating height of the wind turbine used. Generally, the wind speed is measured at a height of 10 meters above the ground $\left(\mathrm{Z}_{0}\right)$. To determine the characteristics of the distribution of wind speeds at heights above $10 \mathrm{~m}$ above ground, extrapolation of the parameters $\mathrm{K}$ and $\mathrm{C}$ of the hybrid Weibull distribution is evaluated using the method of Justus (Justus and Mikhail, 1976; Justus et al., 1978). Thus, if $\mathrm{C}_{1}$ and $\mathrm{K}_{1}$ are the hybrid Weibull parameters, respectively scale and shape parameters at a height $\mathrm{Z}_{1}$, then these parameters at a height $\mathrm{Z}_{2}$ would be obtained from Equations (3) and (5).

$$
\mathrm{C}_{2}=\mathrm{C}_{1}\left(\frac{\mathrm{Z}_{2}}{\mathrm{Z}_{1}}\right)^{\mathrm{N}}
$$

With

$$
\mathrm{N}=\frac{\left[0.37-0.0881 \cdot \ln \left(\mathrm{C}_{1}\right)\right]}{\left[1-0.0881 \cdot \ln \left(\frac{\mathrm{Z}_{1}}{10}\right)\right]}
$$

And

$$
\mathrm{K}_{2}=\frac{\mathrm{K}_{1}}{\left[1-0.0881 \cdot \ln \left(\frac{\mathrm{Z}_{2}}{\mathrm{Z}_{1}}\right)\right]}
$$

Since the kinetic energy of the wind is converted into mechanical energy, the available energy undergoes losses in cascades, until the output energy is released at end the conversion machine (Betz limit, machine thresholds, and conversion losses) (Sahin, 2004).

The average kinetic energy available on a site, per unit time and unit area is expressed by the Equation (6):

$\mathrm{P}=\frac{1}{2} \rho \int_{0}^{+\infty} \mathrm{V}^{3} \mathrm{f}(\mathrm{V}) \mathrm{dV}=\frac{1}{2} \rho \overline{\mathrm{V}^{3}}=\frac{1}{2} \rho \mathrm{C}^{3} \Gamma\left(1+\frac{3}{\mathrm{~K}}\right)$

where:

- $\quad \rho$ is the density of air ( $\mathrm{kg} \mathrm{m}-3)$,

- $\mathrm{V}$ is the wind speed, and

- $\mathrm{f}(\mathrm{V})$ is the distribution function of hybrid Weibull (Equation (1)).

The speed of the wind at the downstream of the wheel being never zero, it is assumed that the wind power is not completely recovered at the propeller. Only a portion of the available average power density is recovered. It is expressed by the Equation (7) (Lu et al., 2002).

$$
\mathrm{P}_{\text {rec }}=\mathrm{C}_{\mathrm{p}} \mathrm{P}
$$

where:

- $\mathrm{C}_{\mathrm{p}}$ is the aerodynamic power coefficient of the machine.

According to Betz, the theoretical maximum aerodynamic power coefficient of the machine $\mathrm{C}_{\mathrm{pmax}}$ is equal to $16 / 27$ or $59.26 \%$. To reach such numbers is extremely difficult. Aerodynamic power coefficients of the best machines today barely reach $50.00 \%$ (Sahin, 2004).

\subsection{Optimal choice of the parameters of a wind turbine}

The variation in power supplied to a load given by a wind turbine provided with a speed regulating device as a function of wind speed, is shown in Figure 2.

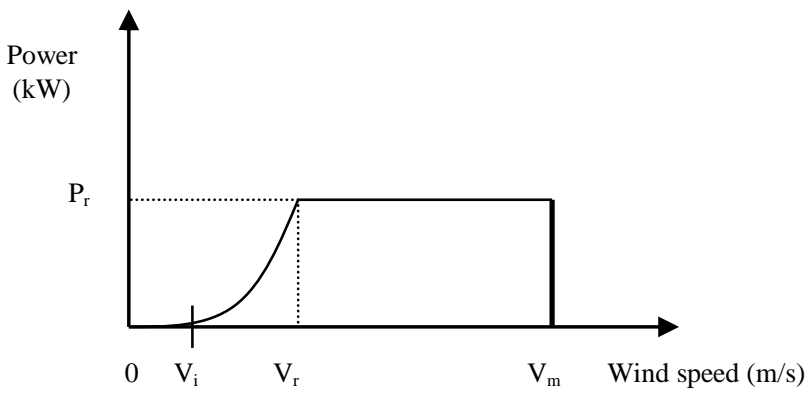

Fig. 2 Energy Power curve of a wind turbine

As presented in Figure 2, $\mathrm{V}_{\mathrm{m}}$ is the speed beyond which the wind turbine has to be stopped to prevent damage; $\mathrm{V}_{\mathrm{i}}$ is the starting speed for which the turbine provides energy; and $V_{r}$ is the rated speed of the wind turbine. Beyond the rated speed $V_{r}$, the control system maintains the power constant and equal to the nominal power.

This curve allows the deduction of the following expressions (Equation (8)) of the power P:

$\mathrm{P}=\left\{\begin{array}{lll}0 & \text { if } & \mathrm{V}<\mathrm{V}_{\mathrm{i}} \\ \mathrm{P}_{1}(\mathrm{~V}) & \text { if } & \mathrm{V}_{\mathrm{i}}<\mathrm{V}<\mathrm{V}_{\mathrm{r}} \\ \mathrm{P}_{\mathrm{r}} & \text { if } & \mathrm{V}_{\mathrm{r}}<\mathrm{V}<\mathrm{V}_{\mathrm{m}} \\ 0 & \text { if } & \mathrm{V}>\mathrm{V}_{\mathrm{m}}\end{array}\right.$

This power is simple expression except in the interval ] $\mathrm{V}_{\mathrm{i}}, \mathrm{V}_{\mathrm{r}}$. . In this interval, the expression of the power can be approximated by a polynomial of degree $n$.

Knowing the distribution function of wind speeds $\mathrm{f}(\mathrm{V})$ and the wind turbine's power curve on the site, the 
average output power $\mathrm{P}_{\text {moy }}$ is given by Equation

(Salami et al., 2013; Al Zohbi et al., 2015).

$P_{\text {moy }}=\int_{V_{i}}^{V_{r}} P_{1}(V) f(V) d V+P_{r} \int_{V_{r}}^{V_{m}} f(V) d V$

where the expression of the power $\mathrm{P}_{1}(\mathrm{~V})$ can be approximated by Equation (10).

$\mathrm{P}_{1}(\mathrm{~V})=\mathrm{a}_{1}+\mathrm{b}_{1} \mathrm{~V}^{\mathrm{K}}$

with:
$\mathrm{b}_{1}=\frac{\mathrm{P}_{\mathrm{r}}}{\left(\mathrm{V}_{\mathrm{r}}^{\mathrm{K}}-\mathrm{V}_{\mathrm{i}}^{\mathrm{K}}\right)}$

where:

- $\mathrm{K}$ is the form factor of hybrid Weibull distribution.

Replacing $\mathrm{f}(\mathrm{V})$ from Equation (9) by its full expression, we get the wind load factor on the site by Equation (13).

$$
\frac{\mathrm{P}_{\text {moy }}}{\mathrm{P}_{\mathrm{r}}}=\left(1-\mathrm{F}_{0}\right)\left[\left(\frac{\mathrm{V}_{\mathrm{r}}}{\mathrm{C}}\right)^{\mathrm{K}}-\left(\frac{\mathrm{V}_{\mathrm{i}}}{\mathrm{C}}\right)^{\mathrm{K}}\right]^{-1}\left\{\exp \left[-\left(\frac{\mathrm{V}_{\mathrm{i}}}{\mathrm{C}}\right)^{\mathrm{K}}\right]-\exp \left[-\left(\frac{\mathrm{V}_{\mathrm{r}}}{\mathrm{C}}\right)^{\mathrm{K}}\right]\right\}-\exp \left[-\left(\frac{\mathrm{V}_{\mathrm{m}}}{\mathrm{C}}\right)^{\mathrm{K}}\right]
$$

with the rated power of the wind turbine as expressed by Equation (14).

$$
\mathrm{P}_{\mathrm{r}}=\eta_{\text {moy }} \mathrm{V}_{\mathrm{r}}^{3}
$$

where:

- $\eta_{\text {moy }}$ represents the average performance of the wind turbine.

Thus, the problem of choosing the parameters of a wind turbine on a site can be formulated as an optimization problem according to the Equation (15).

$$
\begin{gathered}
\left(\hat{\mathrm{V}}_{\mathrm{r}}, \hat{\mathrm{V}}_{\mathrm{i}}\right)=\underset{\mathrm{r} g\left(\max \mathrm{P}_{\text {moy }}\left(\mathrm{V}_{\mathrm{r}}, \mathrm{V}_{\mathrm{i}}\right)\right)}{\arg } \\
\mathrm{V}_{\mathrm{r}} \geq \mathrm{mV}_{\mathrm{i}}
\end{gathered}
$$

where:

- $\hat{\mathrm{V}}_{\mathrm{r}}$ and $\hat{\mathrm{V}}_{\mathrm{i}}$ represent the estimated nominal and optimum start speeds of the wind turbine,

- $\mathrm{m}$ is a positive real number.

Figure 3 shows that an optimal choice of wind turbines parameters on a site is to utilize the maxima of the average power curves produced by the wind turbines on this site. For example, in this figure a wind turbine with a rated speed as twice as its starting speed $\left(\mathrm{V}_{\mathrm{r}}=2 \mathrm{~V}_{\mathrm{i}}\right)$ would produce a maximum average power at the site where the average wind speed of this site is half of the rated speed of the wind turbine.

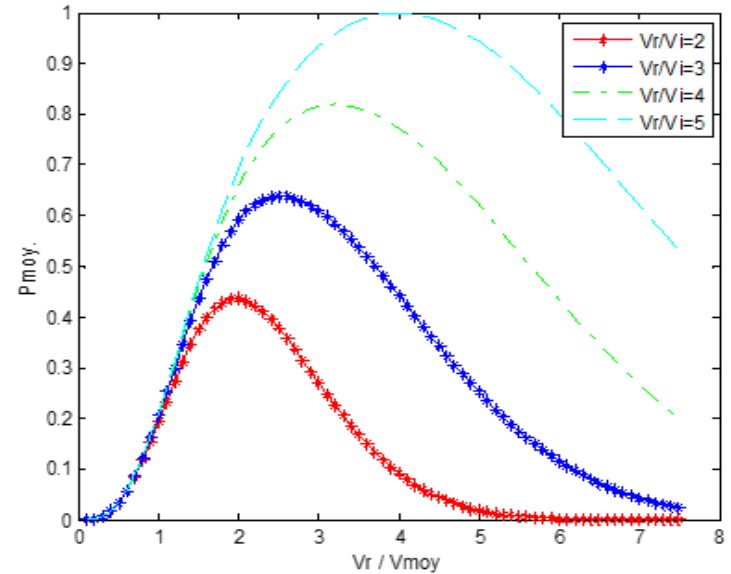

Fig. 3 Average power curves produced for different types of wind turbines

\section{Data processing}

The determination of the parameters of the distribution function of wind speeds, the optimal choice of turbines and the evaluation of the potential for a wind farm given by the methods mentioned previously in this work requires the use of a computer tool for significant time savings, accurate and reliable results. To do so, we have developed a computer application called PotEol (acronym of "Potentiel Eolien") that will help us process the wind data. The computer application PotEol is developed using Scilab to perform the wind data processing. In this article we will discuss only the results provided by this computer application.

PotEol has a graphical interface that allows the user to interact with the application. The main chart of the application PotEol is shown in Figure 4. The software accesses the database of a given site, distributes wind 
speed data following the month, calculates power densities available (using equation (6)) and recoverable (Betz limit) (using equation (7)) and evaluates the wind farm generation on the given site. The application PotEol provides the wind speed histogram and its fitting Weibull curve; the hybrid Weibull parameters and other statistical parameters are sought. The results are given numerically (data tables) and graphically (curves and histograms).

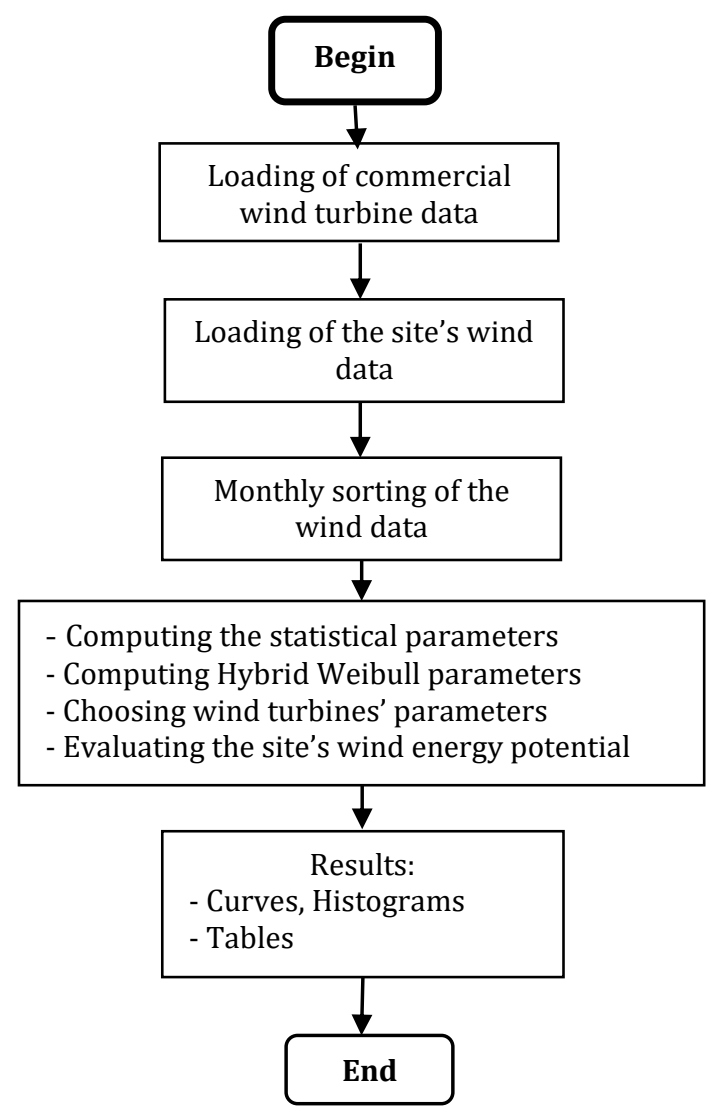

Fig. 4 Main Organization Chart of PotEol

PotEol has a database with a non-exhaustive list of commercial wind turbines. A commercial wind turbine is designated on the main window PotEol as a wind turbine that the user can choose to simulate the production of electricity on the wind site. Each commercial wind turbine is characterized by its rated power, rated speed, and the length of its blades, its starting speed, maximum speed and power curve.

Furthermore, the use of this application allows the user to characterize the distribution of wind speeds, assess the wind potential available from meteorological data for a given site. In addition, the application could determine the optimal wind turbine parameters suitable for optimal production of electrical energy from wind on the site according to relation (15). Thus, the optimal parameters obtained can be retrieved by the user from the main window PotEol for a wind turbine to simulate the production of electricity on a wind farm optimally.
For the remainder of this work, the application PotEol was used to calculate statistical parameters, model the distribution of wind speeds, select optimal parameters of wind turbines, and assess the wind energy potential monthly and annually for the three sites (Lomé, Accra, and Cotonou).

\section{Results and Discussion}

PotEol was applied and based on weather data of the sites Lomé site, Accra site, and Cotonou site yielded the results and discussion that are presented in this section.

\subsection{The statistical parameters of wind speeds data}

After loading the weather data of a site, the statistical parameters of wind speeds of this site were obtained. The parameters obtained for each site are: number of samples, minimum speed, maximum speed, average speed, standard deviations, flattening coefficients (kurtosis), the asymmetry coefficients (skewness), the variation coefficients and hybrid Weibull adjustment function parameters ( $\mathrm{K}, \mathrm{C}$ and $\left.\mathrm{F}_{0}\right)$.

The results for the three (03) studied sites, (Lomé site, Accra site, and Cotonou site) are presented.

\subsubsection{The Lomé site}

Table 1 shows the results of the calculated monthly and yearly statistical parameters of Lomé site.

From the statistical results of Table 1 it was observed that:

- $\quad$ the minimum value of hourly wind speed was 0 $\mathrm{m} / \mathrm{s}$ for all months of the year;

- the maximum speed of $16 \mathrm{~m} / \mathrm{s}$ was recorded during the month of April;

- $\quad$ only the month of July, August, and September had an average speed greater than $4 \mathrm{~m} / \mathrm{s}$ and the maximum monthly average speed of 4.666 $\mathrm{m} / \mathrm{s}$ was recorded for the month of August;

- the standard deviation values were between 1.780 (recorded during the month of December) and 2.161 (recorded during the month of March);

- a maximum kurtosis of 2.679 was recorded for the month of May and minimum kurtosis of 2.267 for the month of February;

- $\quad$ the speeds series of July and August presented lower coefficients of asymmetry (skewness) whereas a strong dissymmetry was recorded during the month of May;

- most variation coefficients (except for the months of July, August, and September) are greater than 0.5 which is the turbulence threshold.

Consequently, it can be observed, from Table 1, that the Lomé site had a low and turbulent wind conditions. According to the Pacific Northwest National Laboratory (PNNL) classification system (Keyhani et al., 2010), 
Citation: Salami, A.A., Ajavon, A.S.A, Kodjo, M.K. and Bédja, K. (2016) Evaluation of Wind Potential for an Optimum Choice of Wind Turbine Generator on the Sites of Lomé, Accra, and Cotonou Located in the Gulf of Guinea. Int. Journal of Renewable Energy Development, 5(3), 211-223, doi : 10.14710/ijred.5.3.211-223 $\mathrm{P}$ a g e $\mid 216$

Lomé site with annual mean wind speed value of 3.520 $\mathrm{m} / \mathrm{s}$ fall outside of the category if based on the year round wind speed. This means that under the current wind turbine technology, this area may not be suitable for year round large-scale electricity generation due to the cost factor. However for small-scale applications, and in the long run with the development of wind turbine technology, the utilization of wind energy is still promising.

Table 1

Results of the calculation of statistical parameters monthly and yearly scale for Lomé site data

\begin{tabular}{|c|c|c|c|c|c|c|c|c|c|c|c|}
\hline Periods & $\begin{array}{c}\text { Numbers } \\
\text { of } \\
\text { samples }\end{array}$ & $\begin{array}{c}V_{\text {moy }} \\
(\mathrm{m} / \mathrm{s})\end{array}$ & $\begin{array}{c}V_{\min } \\
(\mathrm{m} / \mathrm{s})\end{array}$ & $\begin{array}{c}V_{\max } \\
(\mathrm{m} / \mathrm{s})\end{array}$ & $\begin{array}{c}\text { Standard } \\
\text { deviation } \\
(\mathrm{m} / \mathrm{s})\end{array}$ & $\begin{array}{c}\text { Skewness } \\
\text { (-) }\end{array}$ & $\begin{array}{c}\text { Kurtosis } \\
\text { (-) }\end{array}$ & $\begin{array}{c}\text { Coef. of } \\
\text { Variation } \\
\text { (-) }\end{array}$ & $\begin{array}{c}C \\
(\mathrm{~m} / \mathrm{s})\end{array}$ & $\begin{array}{c}K \\
(-)\end{array}$ & $\begin{array}{c}F_{0} \\
(\%)\end{array}$ \\
\hline January & 10992 & 2.758 & 0 & 9 & 1.798 & 0.482 & 2.632 & 0.651 & 3.560 & 1.963 & 8.843 \\
\hline February & 10220 & 3.320 & 0 & 12 & 2.096 & 0.213 & 2.267 & 0.561 & 4.505 & 2.212 & 4.325 \\
\hline March & 11488 & 3.948 & 0 & 10 & 2.161 & 0.150 & 2.286 & 0.547 & 4.805 & 2.115 & 4.370 \\
\hline April & 10701 & 3.640 & 0 & 16 & 2.126 & 0.322 & 2.594 & 0.584 & 4.564 & 1.982 & 4.934 \\
\hline May & 11534 & 3.012 & 0 & 13 & 1.959 & 0.519 & 2.679 & 0.650 & 3.887 & 1.925 & 7.092 \\
\hline June & 11114 & 3.138 & 0 & 12 & 1.933 & 0.466 & 2.623 & 0.616 & 4.044 & 2.046 & 5.498 \\
\hline July & 11167 & 4.209 & 0 & 11 & 1.953 & 0.088 & 2.433 & 0.463 & 5.103 & 2.594 & 1.737 \\
\hline August & 11239 & 4.666 & 0 & 13 & 1.822 & 0.026 & 2.562 & 0.390 & 5.713 & 3.065 & 0.516 \\
\hline September & 11477 & 4.098 & 0 & 10 & 2.019 & 0.169 & 2.374 & 0.492 & 5.046 & 2.478 & 1.889 \\
\hline October & 11935 & 3.231 & 0 & 13 & 1.985 & 0.460 & 2.532 & 0.614 & 4.141 & 2.099 & 4.633 \\
\hline November & 10444 & 2.952 & 0 & 9 & 1.822 & 0.371 & 2.343 & 0.617 & 3.803 & 2.116 & 5.619 \\
\hline December & 10990 & 2.820 & 0 & 9 & 1.780 & 0.370 & 2.386 & 0.631 & 3.62 & 2.047 & 7.425 \\
\hline Annual & 133304 & 3.520 & $\mathbf{0}$ & 16 & 2.040 & 0.308 & 2.423 & 0.581 & 4.382 & 2.086 & 4.725 \\
\hline
\end{tabular}

\subsubsection{The Accra site}

Table 2 presents the results of the calculation of monthly and yearly statistical parameters of Accra site.

The following observations and comments can be made from the statistical results of Table 2 :

1. the minimum value of hourly wind speed was 0 $\mathrm{m} / \mathrm{s}$ for all months of the year;

2. the maximum speed of $21 \mathrm{~m} / \mathrm{s}$ was recorded during the month of July;

3. the month of August presented an average speed greater than $5 \mathrm{~m} / \mathrm{s}$;

4. the standard deviation values were between 1.994 (recorded during the month of December) and 2.359 (recorded during the month of April);

5. a maximum kurtosis of 3.885 was recorded for the month of January and a minimum of 2.267 for the month of February;

6. the speeds series of the months of September and August had the lower coefficients of asymmetry (skewness) whereas a strong dissymmetry were recorded during the month of January;

7. most variation coefficients were greater than 0.5 which is the turbulence threshold.

Based on previous observations from Table 2, it can be said that the Accra site presented turbulent wind conditions. According to the Pacific Northwest National Laboratory (PNNL) classification system (Keyhani et al., 2010), Accra site with annual mean wind speed value of
$4.160 \mathrm{~m} / \mathrm{s}$ fall outside of the category if based on the year round wind speed. This means that under the current wind turbine technology, this area may not be suitable for year round large-scale electricity generation due to the cost factor. However for small-scale applications, and in the long run with the development of wind turbine technology, the utilization of wind energy is still promising.

\subsubsection{The Cotonou site}

Table 3 shows the results of the calculation of monthly and yearly statistical parameters of the Cotonou site.

For the Cotonou site, the following observations and comments can be made from the statistical results of Table 3:

- the minimum value of hourly wind speeds was $0 \mathrm{~m} / \mathrm{s}$ for all months of the year;

- a maximum speed of $14 \mathrm{~m} / \mathrm{s}$ was recorded during the month of October;

- the month of August recorded the greatest average speed $(4.968 \mathrm{~m} / \mathrm{s})$;

- the standard deviation values were between 1.472 (recorded during the month of August) and 1.879 (recorded during the month of June);

- a maximum kurtosis of 3.281 was recorded for the month of January and minimum kurtosis of 2.394 for the month of February;

- the speeds series of the months of March and September had the lower coefficients of 
asymmetry (skewness) whereas a strong dissymmetry were recorded during the month of May;
- most variation coefficients were smaller than 0.5 (the turbulence threshold).

Table 2

Results of the calculation of statistical parameters monthly and yearly scale Accra site data

\begin{tabular}{|c|c|c|c|c|c|c|c|c|c|c|c|}
\hline Periods & $\begin{array}{c}\text { Numbers } \\
\text { of } \\
\text { samples }\end{array}$ & $\begin{array}{l}V_{m o y} \\
(m / s)\end{array}$ & $\begin{array}{c}V_{\min } \\
(\mathrm{m} / \mathrm{s})\end{array}$ & $\begin{array}{l}V_{\max } \\
(\mathrm{m} / \mathrm{s})\end{array}$ & $\begin{array}{c}\text { Standard } \\
\text { deviation } \\
(\mathrm{m} / \mathrm{s})\end{array}$ & $\begin{array}{l}\text { Skewness } \\
(-)\end{array}$ & $\begin{array}{c}\text { Kurtosis } \\
(-)\end{array}$ & $\begin{array}{c}\text { Coef. of } \\
\text { Variation } \\
(-)\end{array}$ & $\begin{array}{c}C \\
(m / s)\end{array}$ & $\begin{array}{c}K \\
(-)\end{array}$ & $\begin{array}{c}F_{0} \\
(\%)\end{array}$ \\
\hline January & 6355 & 3.503 & 0 & 21 & 2.114 & 0.327 & 3.885 & 0.603 & 4.292 & 1.628 & 9.772 \\
\hline February & 5105 & 4.323 & 0 & 11 & 2.228 & 0.032 & 2.498 & 0.515 & 5068 & 2.116 & 5.544 \\
\hline March & 6070 & 4.206 & 0 & 13 & 2.249 & 0.113 & 2.478 & 0.534 & 4.915 & 2.126 & 5.684 \\
\hline April & 5624 & 4.155 & 0 & 13 & 2.359 & 0.139 & 2.436 & 0,567 & 4846 & 1.973 & 7.432 \\
\hline May & 5679 & 3.701 & 0 & 16 & 2.208 & 0.247 & 2.806 & 0.596 & 4.472 & 1.836 & 9.051 \\
\hline June & 5090 & 3.921 & 0 & 15 & 2.187 & 0.079 & 2.571 & 0.557 & 4,634 & 1.970 & 7.701 \\
\hline July & 6210 & 4.842 & 0 & 21 & 2.092 & -0.083 & 3.264 & 0.432 & 5882 & 2.165 & 3.285 \\
\hline August & 6385 & 5.087 & 0 & 18 & 2.014 & -0.190 & 3.342 & 0.395 & 6040 & 2.393 & 3.195 \\
\hline September & 5546 & 4.937 & 0 & 11 & 2.101 & -0.195 & 2.826 & 0.425 & 5745 & 2.373 & 3.552 \\
\hline October & 4834 & 4.187 & 0 & 19 & 2.191 & 0.120 & 2.954 & 0.523 & 5071 & 1.949 & 5.792 \\
\hline November & 5707 & 3.548 & 0 & 18 & 2.024 & 0.263 & 3.333 & 0.570 & 4.406 & 1.804 & 8.200 \\
\hline December & 6127 & 3.475 & 0 & 14 & 1.994 & 0.218 & 2.709 & 0.573 & 4.246 & 1.985 & 7.850 \\
\hline Annual & 68732 & 4.160 & 0 & 21 & 2.215 & 0.088 & 2.766 & 0.532 & 4.993 & 1.894 & 6.412 \\
\hline
\end{tabular}

Table 3

Results of the calculation of monthly and yearly statistical parameters of Cotonou site

\begin{tabular}{|c|c|c|c|c|c|c|c|c|c|c|c|}
\hline Periods & $\begin{array}{c}\text { Numbers } \\
\text { of } \\
\text { samples }\end{array}$ & $\begin{array}{l}V_{\text {moy }} \\
(\mathrm{m} / \mathrm{s})\end{array}$ & $\begin{array}{c}V_{\min } \\
(\mathrm{m} / \mathrm{s})\end{array}$ & $\begin{array}{l}V_{\max } \\
(\mathrm{m} / \mathrm{s})\end{array}$ & $\begin{array}{c}\text { Standard } \\
\text { deviation } \\
(\mathrm{m} / \mathrm{s})\end{array}$ & $\begin{array}{c}\text { Skewness } \\
(-)\end{array}$ & $\begin{array}{c}\text { Kurtosis } \\
(-)\end{array}$ & $\begin{array}{c}\text { Coef. of } \\
\text { Variation } \\
(-)\end{array}$ & $\begin{array}{c}C \\
(m / s)\end{array}$ & $\begin{array}{c}K \\
(-)\end{array}$ & $\begin{array}{c}F_{0} \\
(\%)\end{array}$ \\
\hline January & 11818 & 3.193 & 0 & 9 & 1.611 & 0.074 & 2.486 & 0.504 & 3.991 & 2.424 & 4.282 \\
\hline February & 10648 & 4.347 & 0 & 11 & 1.720 & -0.382 & 2.628 & 0.395 & 5.135 & 2.853 & 1.193 \\
\hline March & 11336 & 4.636 & 0 & 10 & 1.679 & -0.490 & 2.855 & 0.362 & 5.440 & 3.010 & 0.820 \\
\hline April & 10987 & 4.260 & 0 & 13 & 1.814 & -0.159 & 2.862 & 0,425 & 5.204 & 2.541 & 1.866 \\
\hline May & 11185 & 3.543 & 0 & 13 & 1.806 & 0.239 & 2.876 & 0.509 & 4.579 & 2.289 & 2.834 \\
\hline June & 11001 & 3.687 & 0 & 11 & 1.879 & 0.049 & 2.448 & 0.509 & 4.502 & 2.309 & 3.863 \\
\hline July & 11074 & 4.859 & 0 & 11 & 1.694 & -0.403 & 3.138 & 0.348 & 5.701 & 2.934 & 1.156 \\
\hline August & 10931 & 4.968 & 0 & 10 & 1.472 & -0.294 & 3.281 & 0.296 & 5.910 & 3.387 & 0.659 \\
\hline September & 10780 & 4.483 & 0 & 9 & 1.816 & -0.419 & 2.793 & 0.405 & 5.356 & 2.479 & 2.570 \\
\hline October & 11525 & 3.435 & 0 & 14 & 1.787 & 0.103 & 2.489 & 0.520 & 4.352 & 2.216 & 3.766 \\
\hline November & 11340 & 3.403 & 0 & 12 & 1.578 & -0.075 & 2.518 & 0.463 & 4.286 & 2.503 & 2.787 \\
\hline December & 11803 & 3.267 & 0 & 11 & 1.510 & -0.083 & 2.394 & 0.462 & 4.107 & 2.606 & 2.66 \\
\hline Annual & 134428 & 3.993 & $\mathbf{0}$ & 14 & 1.812 & -0.109 & 2.535 & 0.453 & 4.864 & 2.482 & 2.391 \\
\hline
\end{tabular}

Based on the observations from Table 3 , it can be said that turbulent wind conditions prevailed on the Cotonou site. According to the Pacific Northwest National Laboratory (PNNL) classification system (Keyhani et al., 2010), Cotonou site with annual mean wind speed value of $3.993 \mathrm{~m} / \mathrm{s}$ fall outside of the category if based on the year round wind speed. This means that under the current wind turbine technology, this area may not be suitable for year round large-scale electricity generation due to the cost factor. However for small-scale applications, and in the long run with the development of wind turbine technology, the utilization of wind energy is still promising.

\subsection{Evaluation of wind energy potential}

The assessment of wind energy potential is accurate if the wind characteristics used are determined under optimum conditions.

An optimal choice of wind turbines parameters on a site, should take it into consideration the height of the wind generator since the wind farm potential is a function of the height.

5.2.1. Changes in available power densities and recoverable depending on the height of the tower

Densities of recoverable and available powers on a monthly scale were calculated for different towers 
Citation: Salami, A.A., Ajavon, A.S.A, Kodjo, M.K. and Bédja, K. (2016) Evaluation of Wind Potential for an Optimum Choice of Wind Turbine Generator on the Sites of Lomé, Accra, and Cotonou Located in the Gulf of Guinea. Int. Journal of Renewable Energy Development, 5(3), 211-223, doi : 10.14710/ijred.5.3.211-223 P a g e $\mid 218$

heights $(10 \mathrm{~m}, 30 \mathrm{~m}$ and $50 \mathrm{~m})$ for the three sites, to study the changes on sites as a function of the height.

The histograms of Figures 5, 6 and 7 show the changes in available power densities on a monthly scale on the first studied site (the Lomé site), respectively at $10 \mathrm{~m}, 30 \mathrm{~m}$ and $50 \mathrm{~m}$ height.

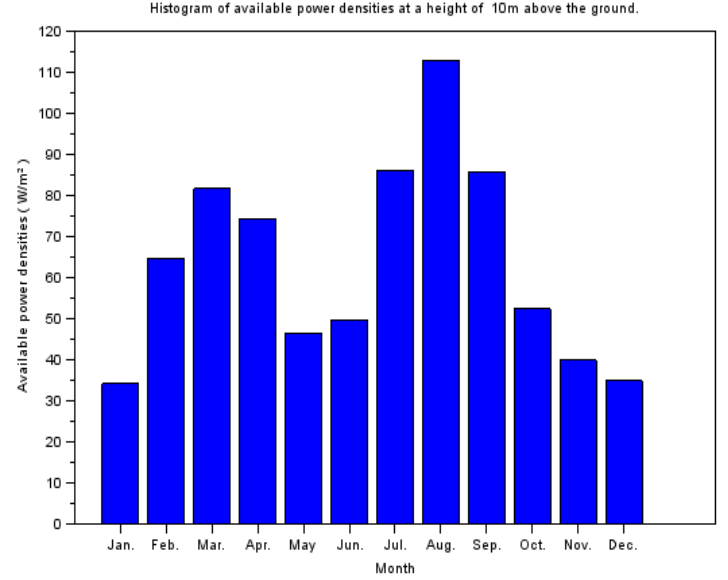

Fig. 5 Histogram of available power densities respectively at $10 \mathrm{~m}$ height on the Lomé site

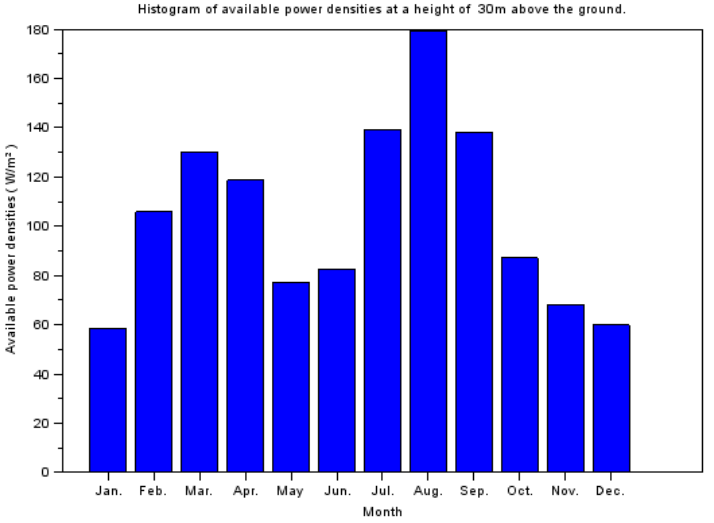

Fig. 6 Histogram of available power densities respectively at $30 \mathrm{~m}$ height on the Lomé site

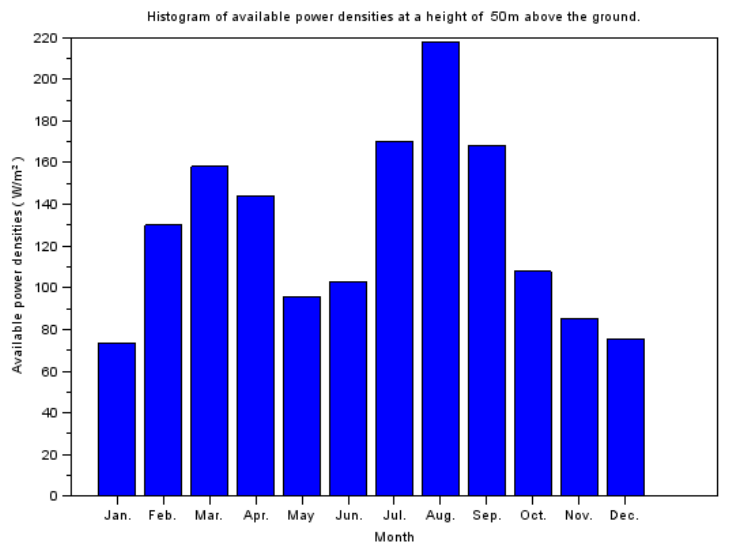

Fig. 7 Histogram of available power densities respectively at $50 \mathrm{~m}$ height on the Lomé site

The histograms of Figures 8, 9 and 10 show the changes in available power densities on a monthly scale on the second studied site (the Accra site), respectively at $10 \mathrm{~m}, 30 \mathrm{~m}$ and $50 \mathrm{~m}$ height.

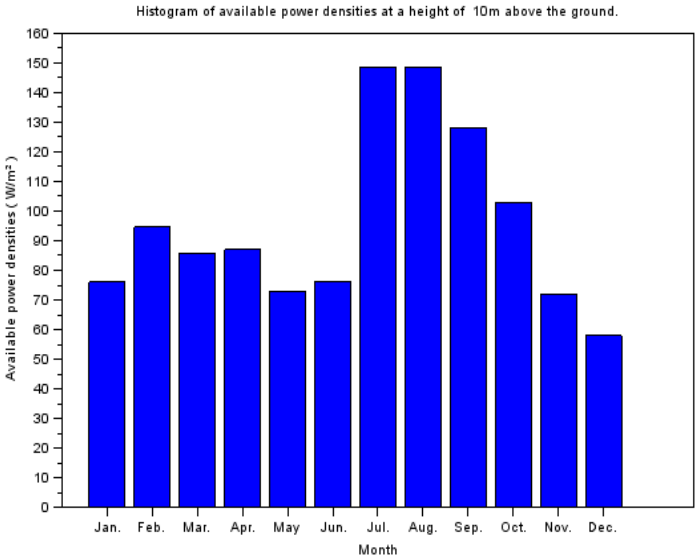

Fig. 8 Histogram of available power densities respectively at $10 \mathrm{~m}$ height on the Accra site

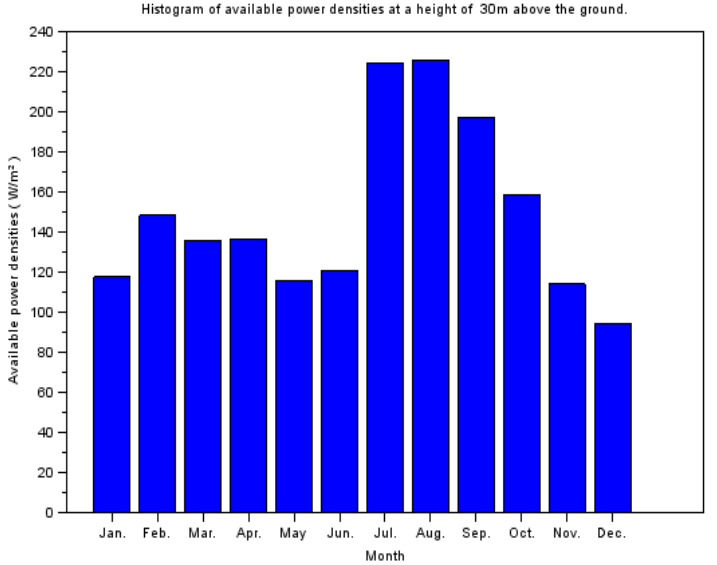

Fig. 9 Histogram of available power densities respectively at $30 \mathrm{~m}$ height on the Accra site

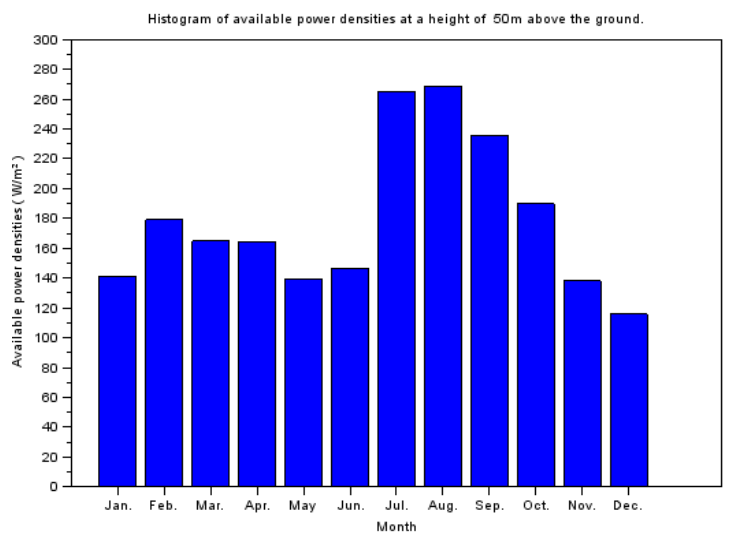

Fig. 10 Histogram of available power densities respectively at 50 $\mathrm{m}$ height on the Accra site

The histograms of Figures 11, 12 and 13 show the changes in available power densities on a monthly scale on the third studied site (the Cotonou site), respectively at $10 \mathrm{~m}, 30 \mathrm{~m}$ and $50 \mathrm{~m}$ height. 


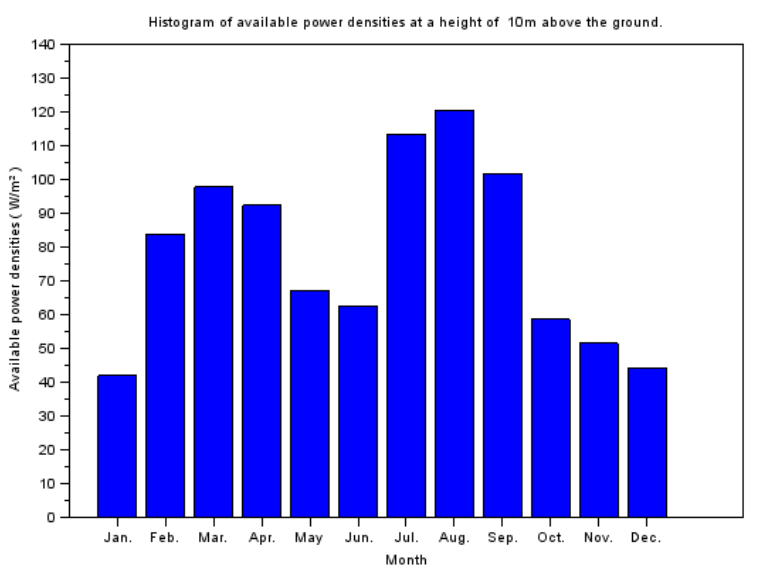

Fig. 11 Histogram of available power densities respectively at 10 $\mathrm{m}$ height on the Cotonou site

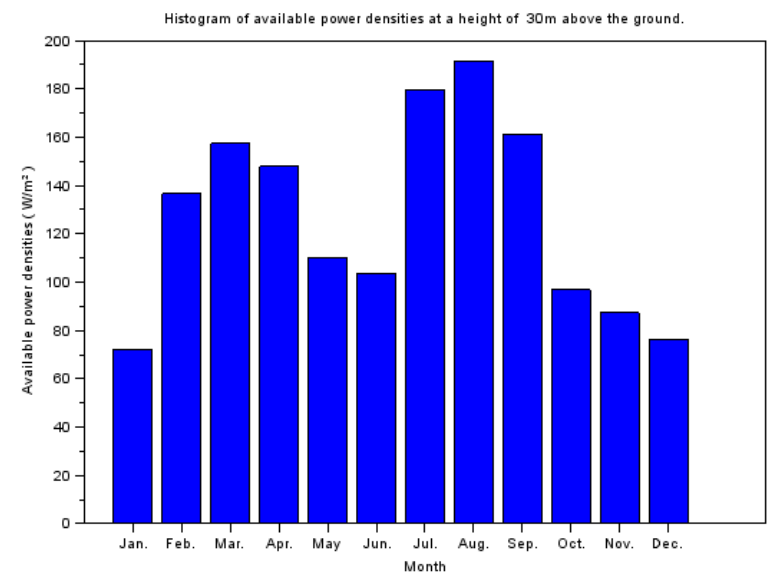

Fig. 12 Histogram of available power densities respectively at 30 $\mathrm{m}$ height on the Cotonou site

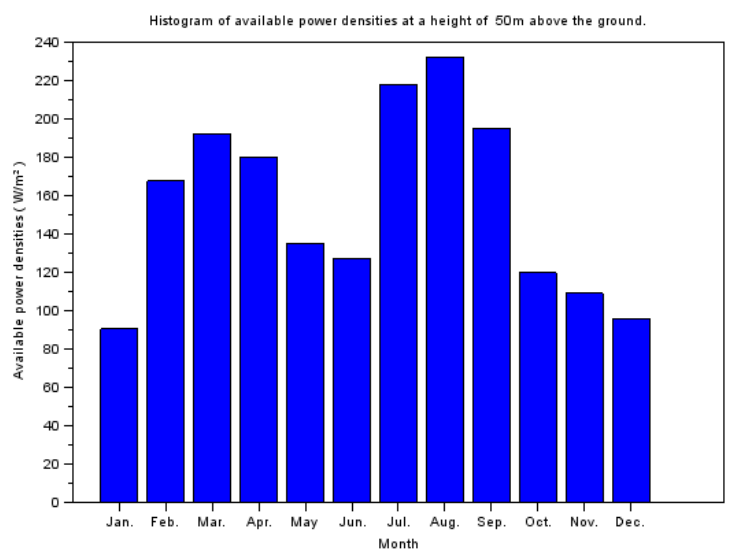

Fig. 13. Histogram of available power densities respectively at 50 $m$ height on the Cotonou site

From the histograms of Figures 5, 6 and 7, we found that the recoverable power densities on the Lomé site increased with the tower height. Additionally, the month of August had the highest power density available and January had the smallest. The minimum and maximum power densities available on a monthly scale on the Lomé site for different heights are respectively about:

1. $\sim 34 \mathrm{~W} / \mathrm{m}^{2}$ and $\sim 112 \mathrm{~W} / \mathrm{m}^{2}$ for a tower height of $10 \mathrm{~m}$;

2. $\sim 58 \mathrm{~W} / \mathrm{m}^{2}$ and $\sim 179 \mathrm{~W} / \mathrm{m}^{2}$ for a tower height of $30 \mathrm{~m}$;

3. $\sim 73 \mathrm{~W} / \mathrm{m}^{2}$ and $\sim 217 \mathrm{~W} / \mathrm{m}^{2}$ for a tower height of $50 \mathrm{~m}$.

Table 4

Power densities available and recoverable for the Lomé site, Accra site and Cotonou site at a height of $50 \mathrm{~m}$ above the ground

\begin{tabular}{|c|c|c|c|c|c|c|}
\hline & \multicolumn{2}{|l|}{ Lomé } & \multicolumn{2}{|l|}{ Accra } & \multicolumn{2}{|l|}{ Cotonou } \\
\hline & $\begin{array}{l}\text { Available } \\
\text { power density } \\
\left(\mathrm{W} / \mathrm{m}^{2}\right)\end{array}$ & $\begin{array}{l}\text { Recoverable } \\
\text { power density } \\
\left(\mathrm{W} / \mathrm{m}^{2}\right)\end{array}$ & $\begin{array}{l}\text { Available } \\
\text { power density } \\
\left(\mathrm{W} / \mathrm{m}^{2}\right)\end{array}$ & $\begin{array}{l}\text { Recoverable } \\
\text { power density } \\
\left(\mathrm{W} / \mathrm{m}^{2}\right)\end{array}$ & $\begin{array}{l}\text { Available } \\
\text { power density } \\
\left(\mathrm{W} / \mathrm{m}^{2}\right)\end{array}$ & $\begin{array}{l}\text { Recoverable } \\
\text { power density } \\
\left(\mathrm{W} / \mathrm{m}^{2}\right)\end{array}$ \\
\hline January & 73.562 & 43.592 & 141.364 & 83.771 & 90.685 & 53.739 \\
\hline February & 130.157 & 77.130 & 179.012 & 106.081 & 167.707 & 99.382 \\
\hline March & 158.060 & 93.669 & 164.713 & 97.608 & 192.133 & 113.857 \\
\hline April & 144.260 & 85.491 & 164.558 & 97.516 & 180.100 & 106.726 \\
\hline May & 95.501 & 56.593 & 139.688 & 82.778 & 135.149 & 80.088 \\
\hline June & 102.571 & 60.782 & 146.348 & 86.725 & 127.378 & 75.483 \\
\hline July & 169.933 & 100.701 & 264.939 & 157.001 & 217.643 & 128.974 \\
\hline August & 217.592 & 128.943 & 268.196 & 158.931 & 231.736 & 137.325 \\
\hline September & 168.153 & 99.646 & 235.848 & 139.762 & 194.723 & 115.391 \\
\hline October & 108.009 & 64.005 & 190.045 & 112.619 & 119.661 & 70.910 \\
\hline November & 85.402 & 50.608 & 137.978 & 81.765 & 108.997 & 64.591 \\
\hline December & 75.513 & 44.748 & 115.999 & 68.740 & 96.061 & 56.925 \\
\hline Annual & 125.357 & 74.286 & 185.786 & 110.095 & 152.162 & 90.170 \\
\hline
\end{tabular}

The Accra site is windier than the Lomé site. The minimum and maximum power densities available on a monthly scale on the Lomé site for different heights are respectively about (see Figures 8, 9 and 10):
1. $\sim 56 \mathrm{~W} / \mathrm{m}^{2}$ and $\sim 148 \mathrm{~W} / \mathrm{m}^{2}$ for a tower height of $10 \mathrm{~m}$;

2. $\sim 94 \mathrm{~W} / \mathrm{m}^{2}$ and $\sim 225 \mathrm{~W} / \mathrm{m}^{2}$ for a tower height of $30 \mathrm{~m}$; 
Citation: Salami, A.A., Ajavon, A.S.A, Kodjo, M.K. and Bédja, K. (2016) Evaluation of Wind Potential for an Optimum Choice of Wind Turbine Generator on the Sites of Lomé, Accra, and Cotonou Located in the Gulf of Guinea. Int. Journal of Renewable Energy Development, 5(3), 211-223, doi : 10.14710/ijred.5.3.211-223 $P$ a g e $\mid 220$

3. $\sim 115 \mathrm{~W} / \mathrm{m}^{2}$ and $\sim 268 \mathrm{~W} / \mathrm{m}^{2}$ for a tower height of $50 \mathrm{~m}$.

Similarly, the values of the minimum and maximum power densities available on a monthly scale on the Cotonou site according to the height are respectively about (see Figures 11, 12 and 13):

1. $\sim 41 \mathrm{~W} / \mathrm{m}^{2}$ and $\sim 120 \mathrm{~W} / \mathrm{m}^{2}$ for a height of 10 $\mathrm{m}$ tower;

2. $\sim 72 \mathrm{~W} / \mathrm{m}^{2}$ and $\sim 191 \mathrm{~W} / \mathrm{m}^{2}$ for a height of 30 $\mathrm{m}$ tower;

3. $\sim 90 \mathrm{~W} / \mathrm{m}^{2}$ and $\sim 231 \mathrm{~W} / \mathrm{m}^{2}$ for a height of 50 $\mathrm{m}$ tower

Table 4 shows the power densities available and recoverable on the three sites at a height of $50 \mathrm{~m}$ above the ground.

It can be noted that there was an uneven distribution of recoverable power densities on a monthly scale at the three sites, which was due to seasonal effects.

$\mathrm{Yu}$ and $\mathrm{Qu}$ (2010) noted that sites of good or excellent resource potential, with the wind power density above $400 \mathrm{~W} / \mathrm{m}^{2}$ or even reach $800 \mathrm{~W} / \mathrm{m}^{2}$ at a height of $50 \mathrm{~m}$, and wind speed more than $7.0 \mathrm{~m} / \mathrm{s}$, are suitable candidates to locate the wind power plants. According to (Yu et al. (2010)) the three sites are not suitable for large-scale electric wind application. But, small-scale wind turbines could be good option for Lomé, Accra and Cotonou sites in order to supply power for lightings, electric fans, chargers and air conditioning units for small houses like proposed by (Mostafaeipour et al. (2011)) for Shahrbabak city in Iran.

\subsubsection{Optimal choice of the parameters of the wind turbine}

To show the importance of a wind turbine design, we randomly chose in a database with a non-exhaustive list of commercial wind turbines one wind turbine. A wind turbine chosen is a wind turbine from the Manufacturer AUROVILLE ENERGY PRODUCT, INDIA (rated power $=5 \mathrm{~kW}$, nominal speed $=14 \mathrm{~m} / \mathrm{s}$, and starting speed $=3.3 \mathrm{~m} / \mathrm{s}$ ) which we named in this study "wind turbine A". Thus, we could compare the load factors and average power produced by wind turbine which is the wind turbine adapted to the site with those produced by a wind turbine ("wind turbine A") we are randomly chosen.

The corresponding power curve of "wind turbine A" selected is given in Figure 14.

In Figure 14, it can be seen that the curve of the adjustment function which characterizes the production of the wind turbine in the starting speed range and nominal speed (] $\mathrm{V}_{\mathrm{i}}, \mathrm{V}_{\mathrm{r}}[)$, had parameters which were estimated with a MSE error of $5.3 \cdot 10^{-9}$ and a correlation coefficient $\mathrm{R}^{2}$ of 0.9 . Therefore from Equation (8), we can express the model of the energy power curve of this wind turbine by Equation (16):

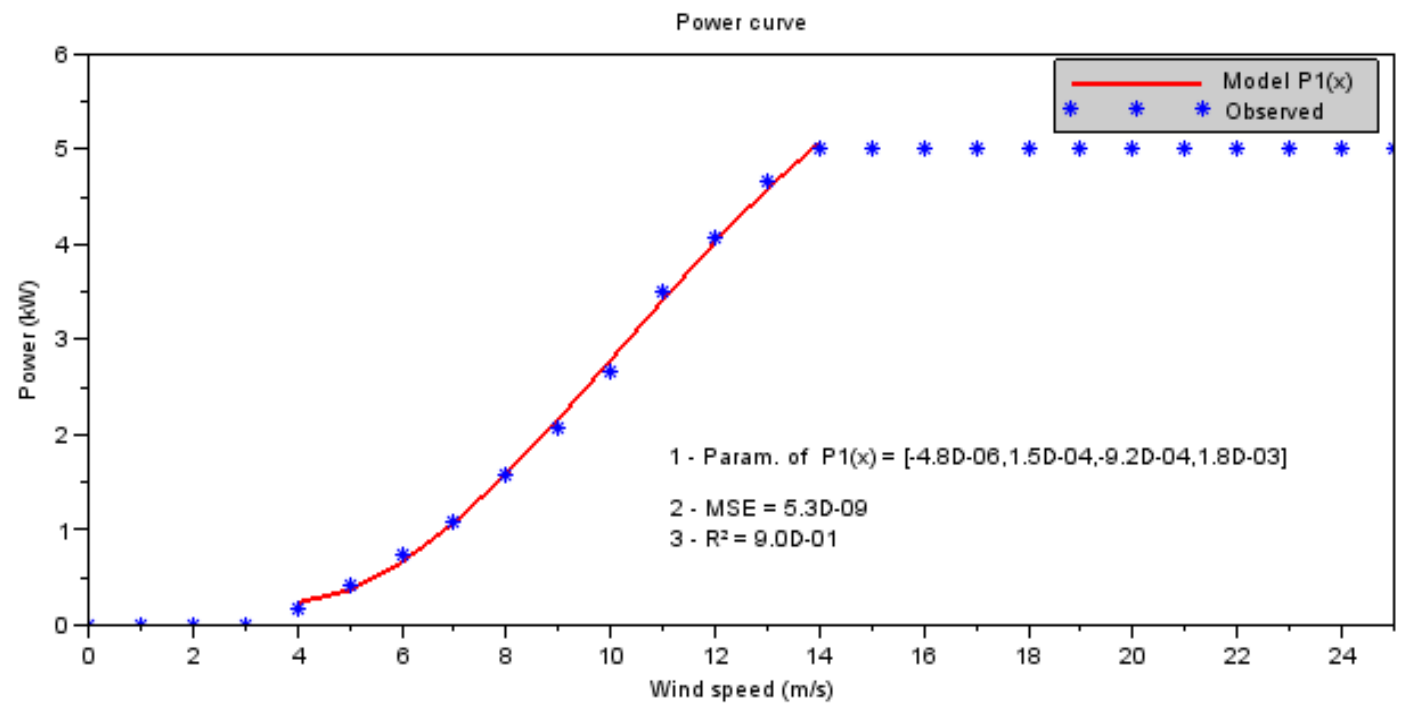

Fig. 14 Power curve of the selected wind turbine A (AUROVILLE AEP 5000)

$$
\mathrm{P}(\mathrm{V})=\left(\begin{array}{ll}
0 & \text { if } \mathrm{V}<3.3 \mathrm{~m} / \mathrm{s} \\
-4.8 \cdot 10^{-6} \mathrm{~V}^{3}+1.495 .10^{-4} \mathrm{~V}^{2}-9.162 .10^{-4} \mathrm{~V}+1.8 .10^{-3} & \text { if } 3.3 \mathrm{~m} / \mathrm{s}<\mathrm{V}<14 \mathrm{~m} / \mathrm{s} \\
5 & \text { if } 14 \mathrm{~m} / \mathrm{s}<\mathrm{V}<25 \mathrm{~m} / \mathrm{s} \\
0 & \text { if } \mathrm{V}>25 \mathrm{~m} / \mathrm{s}
\end{array}\right.
$$


For the optimal choice of wind turbines parameters on the three sites, the height of the towers was set to 50 meters above the ground. From the wind data at $10 \mathrm{~m}$ above ground at the site, the PotEol software determined the hybrid Weibull monthly and yearly scale parameters at a height of $50 \mathrm{~m}$ above the ground and graphed the normalized average power curves produced by different types of wind turbines (Figure 3) using Equation (13).

In this study, we used normalized average powers produced curve. This curve corresponded to a range of wind turbines with a rated speed $\left(\mathrm{V}_{\mathrm{r}}\right)$ as twice as the starting speed $\left(\mathrm{V}_{\mathrm{i}}\right)$. This involved solving the optimization problem of the relation (15) with the constraint $\mathrm{V}_{\mathrm{r}}=2 \mathrm{~V}_{\mathrm{i}} \quad(\mathrm{m}=2)$. Thus, for the constraint $\mathrm{V}_{\mathrm{r}}=2 \mathrm{~V}_{\mathrm{i}}$, the maximum of the curve produced average power was obtained for $\mathrm{V}_{\mathrm{r}}=1.7 \mathrm{~V}_{\text {moy }}$ on the Lomé site (Figure 15).

The corresponding theoretical optimum characteristics of the wind turbine are $V_{r}=8.276 \mathrm{~m} / \mathrm{s}$ and $V_{i}=4.138 \mathrm{~m} / \mathrm{s}$. We therefore chose the standard parameters $V_{r}=8 \mathrm{~m} / \mathrm{s}$ and $V_{i}=4 \mathrm{~m} / \mathrm{s}$ for this site. We named in this study the optimum wind turbine for Lomé site with parameters $\mathrm{V}_{\mathrm{r}}=8 \mathrm{~m} / \mathrm{s}$ and $\mathrm{V}_{\mathrm{i}}=4 \mathrm{~m} / \mathrm{s}$ "wind turbine B".

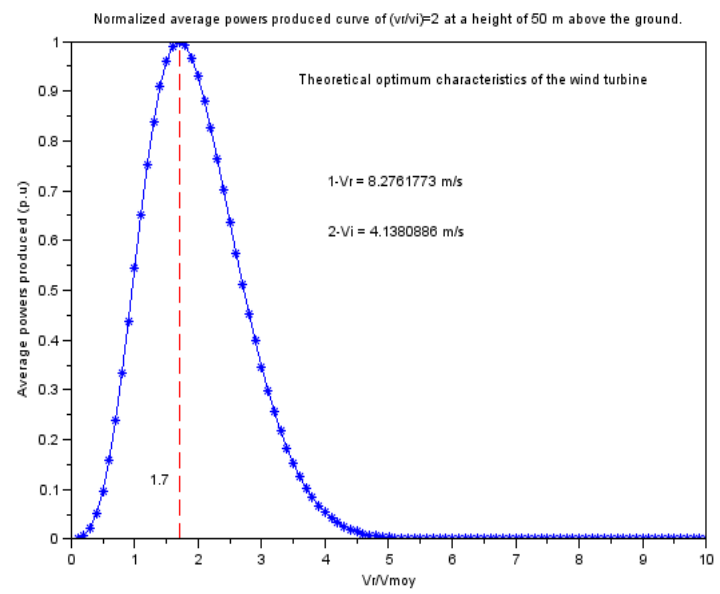

Fig. 15 Normalized average powers produced curve on Lomé site for $\mathrm{V}_{\mathrm{r}}=2 \mathrm{~V}_{\mathrm{i}}$

The corresponding theoretical optimum characteristics of the wind turbine are $V_{\mathrm{r}}=8.276 \mathrm{~m} / \mathrm{s}$ and $\mathrm{V}_{\mathrm{i}}=4.138 \mathrm{~m} / \mathrm{s}$. We therefore chose the standard parameters $V_{r}=8 \mathrm{~m} / \mathrm{s}$ and $V_{i}=4 \mathrm{~m} / \mathrm{s}$ for this site. We named in this study the optimum wind turbine for Lomé site with parameters $\mathrm{V}_{\mathrm{r}}=8 \mathrm{~m} / \mathrm{s}$ and $\mathrm{V}_{\mathrm{i}}=4 \mathrm{~m} / \mathrm{s}$ "wind turbine B".

For the site of Accra, we obtained for $\mathrm{V}_{\mathrm{r}}=1.8 \mathrm{~V}_{\text {moy }}$ (Figure 16) that the theoretical optimal characteristics of the wind turbine corresponded to $\mathrm{V}_{\mathrm{r}}=9.617 \mathrm{~m} / \mathrm{s}$ and $\mathrm{V}_{\mathrm{i}}=4.808 \mathrm{~m} / \mathrm{s}$. Consequently, we chose the standard parameters of $\mathrm{V}_{\mathrm{r}}=10 \mathrm{~m} / \mathrm{s}$ and $\mathrm{V}_{\mathrm{i}}=5 \mathrm{~m} / \mathrm{s}$ for this site. We named in this study the optimum wind turbine for Accra site with parameters $V_{r}=10 \mathrm{~m} / \mathrm{s}$ and $\mathrm{V}_{\mathrm{i}}=5 \mathrm{~m} / \mathrm{s}$ "wind turbine $\mathrm{C}$ ".

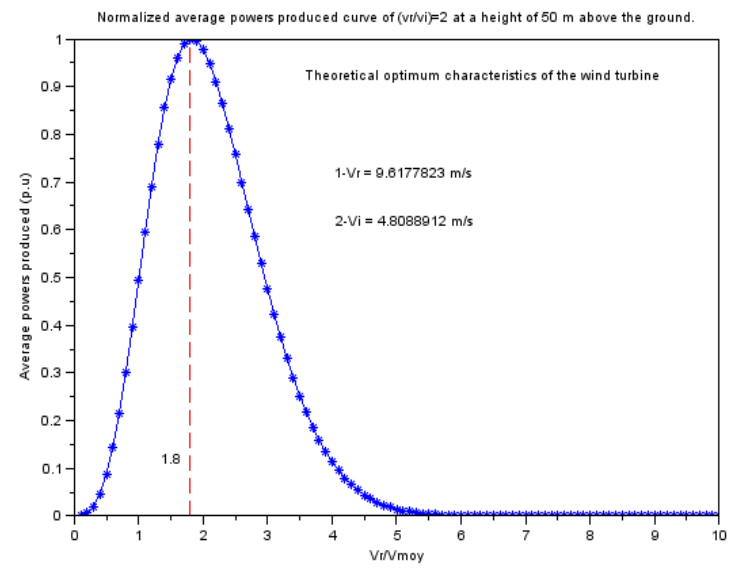

Fig. 16 Normalized average powers produced curve on Accra site for $\mathrm{V}_{\mathrm{r}}=2 \mathrm{~V}_{\mathrm{i}}$

The results for the site of Cotonou are: $\mathrm{V}_{\mathrm{r}}=8.228 \mathrm{~m} / \mathrm{s}$ and $\mathrm{V}_{\mathrm{i}}=4.114 \mathrm{~m} / \mathrm{s}, \quad \mathrm{V}_{\mathrm{r}}=1.5 \mathrm{~V}_{\text {moy }}$ (Figure 17). We chose the standard parameters $\mathrm{V}_{\mathrm{r}}=8 \mathrm{~m} / \mathrm{s}$ and $\mathrm{V}_{\mathrm{i}}=4 \mathrm{~m} / \mathrm{s}$ for this site. We named in this study the optimum wind turbine for Cotonou site with parameters $\mathrm{V}_{\mathrm{r}}=8 \mathrm{~m} / \mathrm{s}$ and $\mathrm{V}_{\mathrm{i}}=4 \mathrm{~m} / \mathrm{s}$ "wind turbine D".

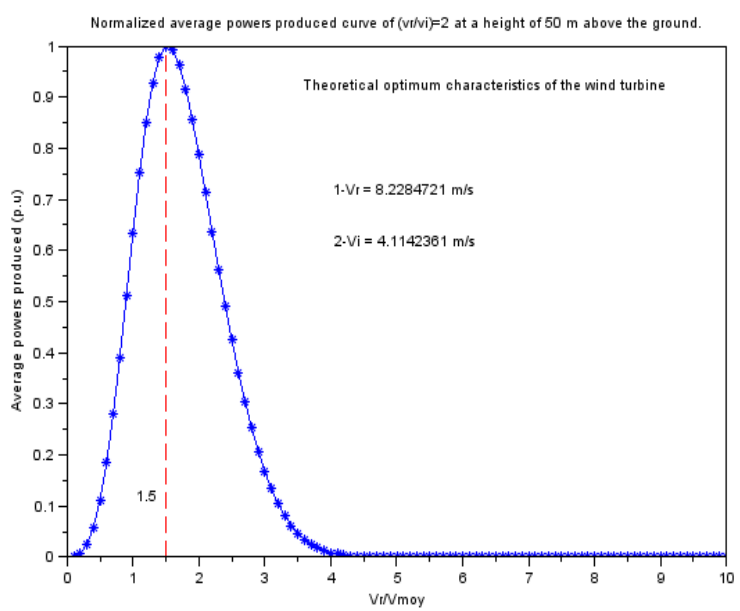

Fig. 17 Normalized average powers produced curve on Cotonou site for $\mathrm{V}_{\mathrm{r}}=2 \mathrm{~V}_{\mathrm{i}}$

The optimum parameters of the wind turbine (for $\mathrm{V}_{\mathrm{r}}=2 \mathrm{~V}_{\mathrm{i}}$ ) obtained for each site were used to evaluate the wind energy potential.

Tables 5 and 6 show the average power produced by this optimal wind turbine selected, load factors, the monthly and annual scale of the Lomé site for the constraint $\mathrm{V}_{\mathrm{r}}=2 \mathrm{~V}_{\mathrm{i}}$. 
Citation: Salami, A.A., Ajavon, A.S.A, Kodjo, M.K. and Bédja, K. (2016) Evaluation of Wind Potential for an Optimum Choice of Wind Turbine Generator on the Sites of Lomé, Accra, and Cotonou Located in the Gulf of Guinea. Int. Journal of Renewable Energy Development, 5(3), 211-223, doi : 10.14710/ijred.5.3.211-223 $\mathrm{P}$ a g e $\mid 222$

The "wind turbine A" on the Lomé site produces an annual average power density of $32.485 \mathrm{~W} / \mathrm{m}^{2}$, with an efficiency of $43.729 \%$ from the Betz limit and a low load factor of $12.757 \%$ against an average power density of $46.212 \mathrm{~W} / \mathrm{m}^{2}, 62.208 \%$ efficiency from the Betz limit, with a load factor of $26.618 \%$ for the "wind turbine B".

The "wind turbine A" on the site of Accra produces an annual average power density of $45.152 \mathrm{~W} / \mathrm{m}^{2}$, with an of $41.011 \%$ from the Betz limit and a low load factor of $17.731 \%$ against an average power density of 67.613 $\mathrm{W} / \mathrm{m}^{2}$, a yield of $61.413 \%$ from the Betz limit, with a load factor of $24.816 \%$ for the "wind turbine C";

The "wind turbine $A$ " on the site of Cotonou produces an annual average power density of 38.863 $\mathrm{W} / \mathrm{m}^{2}$, with an efficiency of $43.099 \%$ from the Betz limit and a low load factor of $15.211 \%$ against an average power density of $56.230 \mathrm{~W} / \mathrm{m}^{2}$ with an efficiency of $62.359 \%$ from the Betz limit and a load factor of $32.956 \%$ for the "wind turbine D".

From simulation results, we can conclude that "wind turbine A" which is randomly selected is not adapted to the three sites, because its efficiencies from the Betz limit were smaller than $50 \%$. The optimal wind turbines obtained for Lomé site ("wind turbine B"), for Accra site ("wind turbine C") and for Cotonou site ("wind turbine D"), have efficiency from the Betz limit higher than 50\%. Optimal wind turbines with rated speeds around $8 \mathrm{~m} / \mathrm{s}$ to $10 \mathrm{~m} / \mathrm{s}$ (small size wind turbines) confirmed that the three sites have poor wind resource potential. This study indicates that small wind turbine projects at the three sites are feasible (Mostafaeipour A. et al., 2011).

Table 5

Average power generated by wind turbines (Case $V_{r}=2 V_{i}$ ) on the three sites

\begin{tabular}{|c|c|c|c|c|c|c|}
\hline & \multirow[b]{2}{*}{$\begin{array}{l}\text { Lomé } \\
\text { Power } \\
\text { densities } \\
\text { produced by } \\
\text { the "wind } \\
\text { turbine A" } \\
\left(\mathrm{W} / \mathrm{m}^{2}\right)\end{array}$} & & \multirow[b]{2}{*}{$\begin{array}{l}\text { Accra } \\
\text { Power } \\
\text { densities } \\
\text { produced by } \\
\text { the "wind } \\
\text { turbine A" } \\
\left(\mathrm{W} / \mathrm{m}^{2}\right)\end{array}$} & \multirow[b]{2}{*}{$\begin{array}{l}\text { Power } \\
\text { densities } \\
\text { produced by } \\
\text { the "wind } \\
\text { turbine C" } \\
\left(\mathrm{W} / \mathrm{m}^{2}\right)\end{array}$} & \multirow[b]{2}{*}{$\begin{array}{c}\text { Cotonou } \\
\text { Power } \\
\text { densities } \\
\text { produced by } \\
\text { the "wind } \\
\text { turbine A" } \\
\left(\mathrm{W} / \mathrm{m}^{2}\right)\end{array}$} & \multirow[b]{2}{*}{$\begin{array}{c}\text { Power densities } \\
\text { produced by the } \\
\text { "wind turbine D" } \\
\left(\mathrm{W} / \mathrm{m}^{2}\right)\end{array}$} \\
\hline & & $\begin{array}{l}\text { Power } \\
\text { densities } \\
\text { produced by } \\
\text { the "wind } \\
\text { turbine B" } \\
\left(\mathrm{W} / \mathrm{m}^{2}\right)\end{array}$ & & & & \\
\hline January & 20.297 & 26.820 & 35.451 & 50.781 & 24.104 & 33.172 \\
\hline February & 33.784 & 47.826 & 44.868 & 66.020 & 42.644 & 61.769 \\
\hline March & 39.921 & 58.483 & 41.908 & 60.858 & 48.422 & 70.693 \\
\hline April & 36.541 & 53.358 & 41.771 & 60.392 & 45.206 & 66.708 \\
\hline May & 25.533 & 34.888 & 36.226 & 50,800 & 34.639 & 50.110 \\
\hline June & 27.094 & 37.606 & 37.902 & 53.617 & 33.145 & 47.199 \\
\hline July & 42.963 & 63.040 & 60.158 & 98.501 & 54.196 & 80.312 \\
\hline August & 54.154 & 79.751 & 62.867 & 99.727 & 57.964 & 84.492 \\
\hline September & 42.368 & 62.169 & 56.896 & 87.665 & 48.539 & 71.987 \\
\hline October & 28.292 & 39.887 & 56.150 & 69.901 & 31.084 & 44.010 \\
\hline November & 22.840 & 31.542 & 35.395 & 50.089 & 28.463 & 40.236 \\
\hline December & 20.585 & 27.444 & 30.944 & 42.626 & 25.176 & 35.581 \\
\hline Annual & 32.485 & 46.212 & 45.152 & 67.613 & 38.863 & 56.230 \\
\hline
\end{tabular}

Table 6

Load factors for wind turbines (Case $V_{r}=2 V_{i}$ ) on the three sites

\begin{tabular}{|c|c|c|c|c|c|c|}
\hline & \multicolumn{2}{|c|}{ Lomé } & \multicolumn{2}{|c|}{ Accra } & \multicolumn{2}{|c|}{ Cotonou } \\
\hline & $\begin{array}{l}\text { Load factor of } \\
\text { the "wind } \\
\text { turbine A" }(\%)\end{array}$ & $\begin{array}{l}\text { Load factor of } \\
\text { the "wind } \\
\text { turbine B" }(\%)\end{array}$ & $\begin{array}{l}\text { Load factor of } \\
\text { the "wind } \\
\text { turbine A" }(\%)\end{array}$ & $\begin{array}{l}\text { Load factor of } \\
\text { the "wind } \\
\text { turbine C" }(\%)\end{array}$ & $\begin{array}{l}\text { Load factor of } \\
\text { the "wind } \\
\text { turbine A" }(\%)\end{array}$ & $\begin{array}{l}\text { Load factor of the } \\
\text { "wind turbine D" } \\
(\%)\end{array}$ \\
\hline January & 7.970 & 25.427 & 13.921 & 19.226 & 9.465 & 34.408 \\
\hline February & 13.267 & 30.252 & 17.619 & 26.810 & 16.746 & 36.628 \\
\hline March & 15.677 & 26.245 & 16.457 & 26.841 & 19.015 & 35.438 \\
\hline May & 10.026 & 24.934 & 14.226 & 22.951 & 13.602 & 28.917 \\
\hline June & 10.639 & 27.319 & 14.884 & 24.846 & 13.016 & 29.350 \\
\hline July & 16.871 & 31.838 & 23.742 & 25.350 & 21.283 & 36.196 \\
\hline August & 21.266 & 34.815 & 24.687 & 28.396 & 22.762 & 41.708 \\
\hline September & 16.638 & 32.670 & 22.340 & 28.749 & 19.061 & 33.111 \\
\hline October & 11.110 & 26.494 & 18.123 & 24.158 & 12.206 & 29.893 \\
\hline November & 8.969 & 26.891 & 13.899 & 22.857 & 11.177 & 33.028 \\
\hline Annual & 12.757 & 26.618 & 17.731 & 24.816 & 15.261 & 32.956 \\
\hline
\end{tabular}




\section{Conclusion}

The current investment in wind power operation is quite expensive compared to conventional energy sources, with the risk of no return on investment. It is therefore imperative to conduct extensive feasibility studies before the establishment of a wind farm. In this regard, we have characterized and assessed the wind energy potential, and studied the optimal choice of wind turbines for annual and monthly scales of the Lomé site, Accra site and Cotonou site located in the Gulf of Guinea.

We evaluated the wind potential at the annual and monthly scale for the sites of the Lomé site, Accra site and Cotonou site located in the Gulf of Guinea. The results showed that these three sites have in general a low wind potential. Also from our study we found that the monthly distribution of the wind on the three sites is not uniform. Thus the months of February, March, April, July, August and September are recommended over other months, for a more profitable operation of the wind farm energy on the three sites. Given the low energy potential on the three sites, wind turbines with low rated speeds of approximately $8 \mathrm{~m} / \mathrm{s}$ to $9 \mathrm{~m} / \mathrm{s}$ on the Lomé site and Cotonou site, and around $9 \mathrm{~m} / \mathrm{s}$ to 10 $\mathrm{m} / \mathrm{s}$ on the Accra site would be most appropriate for optimum exploitation of electric energy from wind farms on these sites from a height of $50 \mathrm{~m}$ above the ground.

\section{References}

Ahmed, S. A. (2013) Comparative Study of Four Methods for Estimating Weibull Parameters for Halabja, Iraq. International Journal of Physical Sciences, 8 (5),186-92.

Ajavon, A. S., Salami, A. A., Kodio, M. K., Bédja, K. (2015). Comparative Characterization Study of the Variability of Wind Energy Potential by Wind Direction Sectors for Three Coastal Sites in Lomé, Accra and Cotonou. Journal of Power Technologies, 95 (2), 134-42.

Akdag, S. A., and Ali, D. (2009) A New Method to Estimate Weibull Parameters for Wind Energy Applications. Energy Conversion and Management, 50 (7), 1761-66.

Al Zohbi, G., Hendrick, P. and Bouillard, P. (2015) Wind Characteristics and Wind Energy Potential Analysis in Five Sites in Lebanon. International Journal of Hydrogen Energy,40(44), 1531115319

Bagiorgas, H. S., Mihalakakou, G., Shafiqur, R., and Al-Hadhrami, L.M. (2011) Weibull Parameters Estimation Using Four Different Methods and Most Energy-Carrying Wind Speed Analysis. International Journal of Green Energy 8 (5),529-54.

Burton, T., Sharpe, D., Jenkins,N. and Bossanyi, E. (2001) Wind Energy Handbook. Wind Energy. 25, Wiley. doi:10.1007/s10661-0112038-2.

Celik, A. N. (2004) A Statistical Analysis of Wind Power Density Based on the Weibull and Rayleigh Models at the Southern Region of Turkey. Renewable Energy, 29 (4), 593-604.

Editorial. (2011) 'Wind Turbine Wakes for Wind Energy.' Wind Energy 14: 797-98. doi:10.1002/we.534.

'http://Wheather.uwyo.edu/surface/meteogram/.' n.d.

Impacts Environmental, Wind-energy Projects Committee, Wind Energy Projects, Council Isbn, This Pdf, National Academies Press, and National Academy. (2007) Environmental Impacts of Wind-Energy Projects. National Academies Press Online.

Jowder, F. A. L. (2009) Wind Power Analysis and Site Matching of Wind Turbine Generators in Kingdom of Bahrain. Applied
Energy, 86 (4), 538-45.

Justus, C. G., Hargraves, W.R., Mikhail, A. and Graber, D. (1978) 'Methods for Estimating Wind Speed Frequency Distributions.' Journal of Applied Meteorology 17 (3), 350-53.

Justus, C. G., and Mikhail, A. (1976) Height Variation of Wind Speed and Wind Distributions Statistics. Geophysical Research Letters' 3 (5), 261-64.

Kaldellis, J. K., and Zafirakis,D. (2011) The Wind Energy (r)evolution: A Short Review of a Long History. Renewable Energy, 36 (7), 1887-1901.

Keyhani, A., Ghasemi-Varnamkhasti, M., Khanali, M., Abbaszadeh, R. (2010) An assessment of wind energy potential as a power generation source in the capital of Iran, Tehran. J Renew Sustain Energy Rev 35,188-201.

Lu, L., Hongxing, Y. and Burnett, J. (2002) Investigation on Wind Power Potential on Hong Kong Islands:an Analysis of Wind Power and Wind Turbine Characteristics. Renewable Energy 27 (1), 1-12.

Manwell J. F., McGowan, J. G. and Rogers, A. L. (2002) Wind Energy Explained. Wind Engineering. doi:10.1002/0470846127.

Mostafaeipour A., Sedaghat A., Dehghan-Niri A. A., V. Kalantar, (2011) Wind energy feasibility study for city of Shahrbabak in Iran, Renewable and Sustainable Energy Reviews, 15,2545-2556.

Rocha, P. A.C., de Sousa, R.C., de Andrade, C.F. and da Silva. M.E.V. (2012) Comparison of Seven Numerical Methods for Determining Weibull Parameters for Wind Energy Generation in the Northeast Region of Brazil. Applied Energy, 89 (1), 395400 .

Sahin,A.D. (2004) Progress and Recent Trends in Wind Energy.' Progress in Energy and Combustion Science, 30 (5), 501-43.

Salami, A.A., Ajavon,A.S.A, Kodjo, M.K and Bedja, K. (2013) Contribution to Improving the Modeling of Wind and Evaluation of the Wind Potential of the Site of Lome: Problems of Taking into Account the Frequency of Calm Winds.' Renewable Energy 50., 449-55.

Stankovic, S., Campbell,N. and Harries,A. (2009) Urban Wind Energy. Refocus. http://books.google.com/books?id= RDL2LhTMcQIC\&pgis=1.

Tong, W. (2010) 'Fundamentals of Wind Energy.' In Wind Power Generation and Wind Turbine Design, 3-42. doi:10.5860/CHOICE.48-3904.

WD. (1996) 'Wind Energy in Spain.' Wind Directions.

$\mathrm{Yu}, \mathrm{X}$. , and $\mathrm{Qu}, \mathrm{H.}$ (2010) 'Wind power in China: Opportunity goes with challenge.' J Renew Sustain Energy Rev 14, 2232-2237. 